\title{
Kesehatan hidung di Sekolah Polisi Negara Karombasan Manado
}

\author{
${ }^{1}$ Lyon Lalita \\ ${ }^{2}$ Ora I. Palandeng \\ ${ }^{2}$ Olivia C. P. Pelealu
}

\author{
${ }^{1}$ Kandidat Skripsi Fakultas Kedokteran Universitas Sam Ratulangi Manado \\ ${ }^{2}$ Bagian/SMF Telinga Hidung Tenggorok-Bedah Kepala Leher Fakultas Kedokteran \\ Universitas Sam Ratulangi - RSUP Prof. Dr. R. D. Kandou Manado \\ Email: lyonlalita@yahoo.com
}

\begin{abstract}
Physiologically, nose has several functions such as a filter and the first-line defence as well as protectve organ against the negative impacts of the environment. The nose is also useful to clean the air from dust, bacteria, and viruses through a mucociliary transport mechanism. Generally, the important role of smell has lack of public attention until eventually disorders or injuries that can disturb the ability and physiological function of the nose occur. This was an observational descriptive study with a cross sectional design. Respondents were 30 students in Sekolah Polisi Negara (State police school) Karombasan Manado; all were males. Nose health status of every respondent was determined by examination of the nasal cavity, conchae, mucous layer, secretion, septum, and post nasal drips. The results showed that from the 30 respondents, there was edema at the right conchae and left conchae each as many as $6.7 \%$. Examination of septum showed that septum deviation of the right nose. Examination of nasal cavity, mucosa layer, secretion and post nasal drips overall resulted in normal category. Conclusion: Nose health status at Sekolah Polisi Negara Karombasan Manado was categorized as good.
\end{abstract}

Keywords: nose health, physical examination of nose

\begin{abstract}
Abstrak: Secara fisiologis hidung mempunyai beberapa fungsi antara lain sebagai penyaring dan pertahanan lini pertama serta pelindung tubuh terpenting terhadap lingkungan yang tidak menguntungkan. Hidung juga berguna membersihkan udara inspirasi dari debu, bakteri dan virus melalui mekanisme transpor mukosiliar. Umumnya, peran penting dari indera penghiduan kurang mendapat perhatian khusus dari masyarakat sendiri hingga terjadi gangguan atau cidera yang dapat menghilangkan kemampuan dan fungsi fisiologis dari organ hidung. Penelitian ini bertujuan untuk mendapatkangambaran kesehatan hidung di Sekolah Polisi Negara Karombasan Manado. Jenis penelitian ialah deskriptif observasional dengan desain potong lintang. Sampel penelitian ialah 30 orang mahasiswa Sekolah Polisi Negara Karombasan Manado, seluruhnya berjenis kelamin laki-laki. Status kesehatan hidung setiap responden dinilai dengan memeriksa kavum nasi, konka, mukosa, sekret, septum, dan post nasal drip. Hasil pemeriksaan menunjukkan dari 30 mahasiswa, terdapat edema pada konka sebelah kanan dan kiri masing-masing sebesar 6,7\%. Hasil pemeriksaan septum, ditemukan deviasi septum pada hidung kanan sebesar 3,3\%. Pada pemeriksaan kavum nasi, mukosa, sekret, dan post nasal drips didapatkan hasil yang normal. Simpulan: Secara keseluruhan kesehatan hidung di Sekolah Polisi Negara Karombasan tergolong baik.
\end{abstract}

Kata kunci: kesehatan hidung, pemeriksaan fisik hidung

Secara fisiologis hidung mempunyai beberapa fungsi seperti sebagai penyaring dan pertahanan lini pertama dan pelindung tubuh terpenting terhadap lingkungan yang 
tidak menguntungkan. Hidung juga berguna membersihkan udara inspirasi dari debu, bakteri dan virus melalui suatu mekanisme yang disebut transpor mukosiliar. ${ }^{1}$ Berdasarkan teori struktural, teori evolusioner, dan teori fungsional, fungsi fisiologis hidung dan sinus paranasal ialah: respirasi, penghidu, fonetik, statik dan mekanik, dan nasal. ${ }^{2}$

Dewasa ini semakin banyak penelitian dan publikasi ilmiah yang didedikasikan terhadap bahaya kerja dan polutan udara, suatu pemahaman mendasar mengenai hidung adalah penting. ${ }^{3}$ Pada umumnya, peran penting dari indera penghiduan kurang mendapat perhatian khusus dari masyarakat sendiri, hingga pada akhirnya timbulnya gangguan atau cidera yang dapat menghilangkan kemampuan dan fungsi fisiologis dari organ hidung. ${ }^{4}$ Keluhan utama penyakit atau kelainan dihidung adalah sumbatan hidung; sekret dihidung dan tenggorok, bersin, rasa nyeri di daerah muka dan kepala, perdarahan dari hidung, dan gangguan penghidu. ${ }^{2}$

Beberapa kelainan pada hidung yang dapat kita temukan antara lain rinitis alergi, polip hidung, sinusitis, dan epistaksis. Prevalensi rinitis alergi cukup bervariasi di setiap belahan dunia. Menurut Stewart et al. prevalensi rinitis alergi di seluruh dunia sekitar 10-40\%. Bauchau dan Durham melaporkan bahwa prevalensi rinitis alergi pada populasi dewasa di Eropa berdasarkan The European Community Respiratory Health Survey sebesar 21\% dan pada beberapa negara di Eropa seperti di Belgia sebesar 28,5\%, Perancis 24,5\%, Italia $16,9 \%$, Inggris $26 \%$, dan Spanyol 21,5\%. ${ }^{5}$

Prevalensi polip hidung pada populasi secara umum sekitar 4\%, akan tetapi studi lain menunjukkan bahwa prevalensi ini telah meningkat hingga $40 \%$. Kejadian ini sering terjadi pada orang dewasa khususnya usia lebih dari 20 tahun. Pada anak-anak di bawah usia 10 tahun tidak biasa terjadi polip hidung melainkan kista fibrosis. Perbandingan kejadian polip hidung berdasarkan jenis kelamin 2:1 dimana lakilaki lebih dominan. ${ }^{6}$

Sinusitis merupakan penyakita yang sering ditemukan dalam praktek dokter sehari-hari, bahkan dianggap sebagai salah satu penyebab gangguan kesehatan tersering di dunia. ${ }^{2}$ Di Amerika Serikat, kejadian sinusitis mencapai angka 31 juta pasien. ${ }^{7}$ Di Indonesia, prevalensi sinusitis termasuk tinggi. Hal ini dapat diketahui berdasarkan data Depkes RI tahun 2003 yang menyebutkan bahwa penyakit tersebut berada pada urutan ke-25 dari 50 pola penyakit. ${ }^{8}$

Prevalensi epistaksis pada laki-laki dan perempuan umumnya sama, dan distribusi usia penderita epistaksis biasanya terjadi pada usia $<20$ tahun dan $>40$ tahun. Pada Januari 2002 sampai Agustus 2007 berdasarkan penelitian yang dilakukan oleh Etnic Comitte of Hospital Clinicals, Faculty of Medicine in Brazil tercatat 40 pasien yang terdiagnosis dengan epistaksis terdiri dari 27 pasien $(67,5 \%)$ perempuan dan 13 pasien $(32,5 \%)$ laki-laki. Usia berkisar antara 4 sampai 78 tahun, tetapi rata-rata terjadi pada usia 20-40 tahun, dan usia anak SD.

\section{METODE PENELITIAN}

Jenis penelitian ialah deskriptif observasional dengan desain potong lintang. Sampel penelitian ialah mahasiswa Sekolah Polisi Negara Karombasan Manado, seluruhnya berjenis kelamin lakilaki. Pada penelitian ini dilakukan survei kesehatan hidung di Sekolah Polisi Negara di Kelurahan Karombasan Manado untuk menilai status kesehatan hidung mahasiswa.

\section{HASIL PENELITIAN}

Berdasarkan penelitian deskriptif observasional tentang kesehatan hidung di Sekolah Polisi Negara Karombasan Manado didapatkan 30 responden laki-laki yang bersedia mengikuti pemeriksaan THT-KL.

Tabel 1 memperlihatkan distribusi berdasarkan usia dengan usia terbanyak ialah 18 tahun berjumlah 12 responden (40\%) dan yang paling sedikit ialah yang berusia 17 tahun dan 21 tahun; maasingmasing berjumlah 1 responden $(3,3 \%)$. 
Tabel 2. Distribusi berdasarkan umur

\begin{tabular}{ccc}
\hline Usia & $\mathbf{N}$ & $\mathbf{\%}$ \\
\hline 17 tahun & 1 & 3,3 \\
18 tahun & 12 & 40 \\
19 tahun & 8 & 26,6 \\
20 tahun & 8 & 26,6 \\
21 tahun & 1 & 3,3 \\
Total & 30 & 100 \\
\hline
\end{tabular}

Pemeriksaan status kesehatan hidung terdiri dari pemeriksaan pada kavum nasi, konka, mukosa, sekret, septum, dan post nasal drips. Pemeriksaan pada kavum nasi kita melihat apakah lapang, sempit atau ada massa. Berdasarkan penelitian pada 30 responden, didapatkan $100 \%$ responden memiliki keadaan kavum nasi yang normal. Tidak ditemukan adanya keadaan abnormal pada kavum nasi seluruh responden (Tabel 2).

Tabel 2. Distribusi berdasarkan keadaan kavum nasi

\begin{tabular}{lcccc}
\hline Kavum & \multicolumn{2}{c}{$\mathbf{N}$} & \multicolumn{2}{c}{$\%$} \\
\cline { 2 - 5 } \multicolumn{1}{c}{ nasi } & Kanan & Kiri & Kanan & Kiri \\
\hline Normal & 30 & 30 & 100 & 100 \\
Lapang & 0 & 0 & 0 & 0 \\
Sempit & 0 & 0 & 0 & 0 \\
Massa & 0 & 0 & 0 & 0 \\
Total & 30 & 30 & 100 & 100 \\
\hline
\end{tabular}

Pada pemeriksaan konka didapatkan keadaan normal pada konka kanan berjumlah 28 responden $(93,3 \%)$ dan pada konka kiri berjumlah 28 responden $(93,3 \%)$. Kelainan yang didapat pada konka yaitu terdapat edema pada konka kanan sebanyak 2 responden $(6,7 \%)$ dan konka kiri sebanyak 2 responden $(6,7 \%)$. Tidak ditemukan keadaan hiperemis, pucat, hipertrofi dan atrofi pada konka kanan maupun kiri (Tabel 3).

Pemeriksaan mukosa dibagi menjadi kategori normal, hiperemis, dan livide. Berdasarkan hasil penelitian, didapatkan $100 \%$ responden memiliki keadaan mukosa yang normal. Tidak ditemukan adanya kelainan pada mukosa seluruh responden (Tabel 4).
Tabel 3. Distribusi berdasarkan keadaan konka

\begin{tabular}{lcccc}
\hline \multirow{2}{*}{ Konka } & \multicolumn{2}{c}{$\mathbf{N}$} & \multicolumn{2}{c}{$\%$} \\
\cline { 2 - 5 } & Kanan & Kiri & Kanan & Kiri \\
\hline Normal & 28 & 28 & 93,3 & 93,3 \\
Edema & 2 & 2 & 6,7 & 6,7 \\
Hiperemis & 0 & 0 & 0 & 0 \\
Pucat & 0 & 0 & 0 & 0 \\
Hipertrofi & 0 & 0 & 0 & 0 \\
Atrofi & 0 & 0 & 0 & 0 \\
Total & 30 & 30 & 100 & 100 \\
\hline
\end{tabular}

Tabel 4. Distribusi berdasarkan keadaan mukosa

\begin{tabular}{lllll}
\hline Mukosa & \multicolumn{2}{c}{$\mathbf{N}$} & \multicolumn{3}{c}{$\%$} \\
\cline { 2 - 5 } & Kanan & Kiri & Kanan & Kiri \\
Normal & 30 & 30 & 100 & 100 \\
Hiperemis & 0 & 0 & 0 & 0 \\
Livide & 0 & 0 & 0 & 0 \\
Total & 30 & 30 & 100 & 100 \\
\hline
\end{tabular}

Pemeriksaan sekret dibagi menjadi kategori tidak ada sekret, serous, mukoid, dan purulen. Dari penelitian ini, didapatkan $100 \%$ responden tidak memiliki sekret. Tidak ditemukan adanya sekret serous, mukoid dan purulent pada semua responden (Tabel 5).

Tabel 5. Distribusi berdasarkan keadaan sekret

\begin{tabular}{lcccc}
\hline \multirow{2}{*}{ Sekret } & \multicolumn{2}{c}{$\mathrm{N}$} & \multicolumn{2}{c}{$\%$} \\
\cline { 2 - 5 } & Kanan & Kiri & Kanan & Kiri \\
\hline Tidak & & & & \\
ada & 30 & 30 & 100 & 100 \\
sekret & & & & \\
Serous & 0 & 0 & 0 & 0 \\
Mukoid & 0 & 0 & 0 & 0 \\
Purulent & 0 & 0 & 0 & 0 \\
Total & 30 & 30 & 100 & 100 \\
\hline
\end{tabular}

Hasil pemeriksaan septum, dapat dibagi menjadi kategori normal, deviasi, abses, dan hematoma. Didapatkan keadaan normal pada septum kanan berjumlah 29 responden $(96,7 \%)$ dan pada septum kiri berjumlah 30 responden $(100 \%)$. Terdapat kelainan pada septum berupa deviasi, dengan hasil pada septum kanan sebanyak 1 orang $(3,3 \%)$. Tidak ditemukan kelainan pada septum kiri, juga keadaan abses dan hematoma (Tabel 6). 
Tabel 6. Distribusi berdasarkan keadaan septum

\begin{tabular}{lllll}
\hline \multirow{2}{*}{ Septum } & \multicolumn{2}{c}{$\mathbf{N}$} & \multicolumn{2}{c}{$\%$} \\
\cline { 2 - 5 } & Kanan & Kiri & Kanan & Kiri \\
Normal & 29 & 30 & 96,7 & 100 \\
Deviasi & 1 & 0 & 3,3 & 0 \\
Abses & 0 & 0 & 0 & 0 \\
Hematoma & 0 & 0 & 0 & 0 \\
Total & 30 & 30 & 100 & 100 \\
\hline
\end{tabular}

Hasil pemeriksaan kita melihat apakah ada atau tidaknya post nasal drips. Berdasarkan hasil penelitian, didapat $100 \%$ responden ditemukan tidak adanya post nasal drip. Hasil penelitian dapa dilihat pada Tabel 8.

Tabel 7. Distribusi berdasarkan keadaan post nasal drips

\begin{tabular}{lcccc}
\hline Post nasal & \multicolumn{2}{c}{$\mathbf{N}$} & \multicolumn{2}{c}{$\%$} \\
\cline { 2 - 5 } \multicolumn{1}{c}{ drips } & Kanan & Kiri & Kanan & Kiri \\
\hline Ada & 0 & 0 & 0 & 0 \\
Tidak & 30 & 30 & 100 & 100 \\
Total & 30 & 30 & 100 & 100 \\
\hline
\end{tabular}

\section{BAHASAN}

Penelitian survei kesehatan hidung ini, dilakukan pada mahasiswa Sekolah Polisi Negara Karombasan Manado dengan desain potong lintang. Penelitian ini diikuti oleh 30 orang yang bersedia menjadi responden penelitian dengan persentase jenis kelamin laki-laki (100\%).

Berdasarkan pemeriksaan kavum nasi pada responden, didapat keadaaan normal pada kavum nasi kanan maupun kiri dari seluruh responden yang diteliti atau $100 \%$ dari seluruh sampel penelitian. Hasil ini menunjukkan status kesehatan yag lebih baik dibandingkan penelitian sebelumnya yang dilakukan oleh Poli et al. ${ }^{10}$ terhadap siswa SMA Negeri 9 Binsus Manado sebanyak 35 anak yang mendapatkan hasil normal hanya pada 32 siswa $(91,43 \%)$.

Gangguan yang sering terjadi pada kavum nasi yaitu polip hidung. Prevalensi polip hidung di dunia bervariasi mulai dari 1-4\% sedangkan insidennya di Rumah Sakit Saiful Anwar tahun 2011 sekitar $0,6 \%$ dari 4.632 kasus baru. Kejadiannya lebih banyak pada laki-laki dibandingkan perempuan (perbandingan 2-4:1). ${ }^{11}$ Pada pemeriksaan konka kanan dan kiri, sebanyak 2 orang responden memiliki edema baik hidung kanan maupun kiri, sisanya normal. Pembengkakan konka dapat disebabkan oleh alergi, paparan polusi iritan, atau peradangan persisten dalam sinus yang juga menyebabkan kerusakan pada silia yang berakibat selain penyumbatan pada hidung, silia yang sudah rusak menjadi media yang baik untuk pertumbuhan bakteri. ${ }^{11}$ Kondisi ini menjadi alasan ditemukannya edema pada beberapa responden. Penelitian yang dilakukan oleh Poli et al. ${ }^{10}$ terhadap siswa SMA Negeri 9 Binsus Manado memberikan hasil yang lebih tinggi dimana prevalensi kejadian edema pada 35 orang sebesar 14,29\% pada hidung kanan maupun kiri. ${ }^{10}$

Pada pemeriksaan septum, didapatkan 1 responden memiliki deviasi septum pada hidung kanan yaitu 3,3\% dari responden penelitian. Deviasi septum didefinisikan sebagai bentuk septum yang tidak lurus di tengah sehingga membentuk deviasi ke salah satu rongga hidung atau kedua rongga hidung yang mengakibatkan penyempitan pada rongga hidung. ${ }^{12}$ Umumnya disebabkan oleh trauma langsung dan biasanya berhubungan dengan kerusakan pada bagian lain hidung seperti fraktur os nasal. ${ }^{13}$ Penelitian yang dilakukan sebelumnya juga maloprkan diantara 2.112 orang dewasa, kejadian deviasi septum adalah $79 \% .{ }^{14}$ Meskipun melewati seleksi kesehatan yang begitu ketat, akan tetapi dengan banyaknya aktifitas fisik yang dilakukan selama menempuh pendidikan di Sekolah Polisi tidak menutup kemungkinan akan terjadi trauma secara langsung yang merupakan penyebab umum deviasi septum. Berdasarkan hasil penelitian diatas, kesehatan hidung di Sekolah Polisi Negara Karombasan tergolong baik.

\section{SIMPULAN}

Berdasarkan hasil penelitian yang dilakukan dapat disimpulkan keadaan kesehatan hidung dari mahasiswa Sekolah Polisi Negara Karombasan Manado tergolong baik. 


\section{SARAN}

1. Perlu adanya pemeriksaan kesehatan secara berkala di tiap instansi terkait.

2. Perlu dilakukan penelitian lebih lanjut mengenai kesehatan hidung, agar bisa mendeteksi lebih dini masalah kesehatan hidung.

\section{DAFTAR PUSTKA}

1. Irfandy D. Transpor mukosiliar pada septum deviasi. Sumatera Barat: Fakultas Kedokteran Universitas Andalas; 2011

2. Soepardi EA, Iskandar N, Bashiruddin J, Restuti RD. Buku Ajar Ilmu Kesehatan Telinga Hidung Tenggorok Kepala \& Leher (7th ed). Jakarta: Balai Penerbit FKUI, 2012.

3. George L, Adams, Lawrence R, Boies, Peter H, Highler. Buku Ajar Penyakit THT (6th ed). Jakarta: EGC, 2012.

4. Silverthorn DU. Fisiologi Manusia: Sebuah Pendekatan Terintegrasi (6th ed). Jakarta: EGC, 2013; p. 355.

5. Pitarini AP, Irawati N, Poerbonegoro NL, Wulandari D, Badarsono $S$. Perubahan kualitas hidup, eosinofil mukosa hidung, dan interleukin-5 serum pasien rinitis alergi pasca terapi. Jakarta: Fakultas Kedokteran Universitas Indonesia. 2015.

6. Newton J, Wong $\mathbf{K}$. A review of nasal polyps. 2008. Available from: https://www.ncbi.nlm.nih.gov/pmc/ar ticles/PMC2504067/.
7. Dykewicz M, Hamilos D. Rhinitis and Sinustis. 2009. Available from: www.jacionline.org/article/S00916749(09)02881-4/.

8. Depkes RI, 2003. Indikator Indonesia Sehat Tahun 2010. Jakarta: Depkes RI.

9. Soepardi EA, Iskandar N, Bashiruddin J, Restuti RD. Buku Ajar Ilmu Kesehatan Telinga Hidung Tenggorok Kepala \& Leher (6th ed). Jakarta: Balai Penerbit FKU, 2007.

10. Poli C, Palandeng O, Tumbel R. Kesehatah hidung siswa SMA Negeri 9 Manado [Skripsi]. Manado: Fakultas Kedokteran Universitas Sam Ratulangi; 2016.

11. Maramis F, Palandeng $O$, Pelealu $O$. Kesehatan hidung pada siswa-siswi Sekolah Dasar Negeri 11 Manado [Skripsi]. Manado: Fakultas Kedokteran Universitas Sam Ratulangi; 2016.

12. Budiman B, Huriati E, Bachtiar $\mathbf{H}$. Pengaruh septoplasti terhadap sumbatan hidung. Sumatera Barat: Fakultas Kedokteran Universitas Andalas; 2014.

13. Budiman B, Asyari A. Pengukuran sumbatan hidung pada deviasi septum nasi. Sumatera Barat: Fakultas Kedokteran Universitas Andalas; 2012.

14. Harar R, Chadha K, Rogers G. The role of septal deviation in adult chronic rhinosinusitis. Rhinology 2004; 42:126-30. 